\title{
The Relationship between Job Satisfaction, Organizational Commitment and Leader- Member Exchange on Turnover Intention (Case Study in Head Office Employee of PT. WG)
}

\author{
Budi Wijaya ${ }^{1}$, Bustanul Arifin Noer ${ }^{2}$
}

\begin{abstract}
The problem of turnover is experienced by many companies, including PT. WG. Head office of PT. WG has the highest rate of turnover among all locations of PT. WG. This study aims to determine the effect of job satisfaction, organizational commitment, and the relationship between leaders and the employees (LeaderMember Exchange - LMX) on employee turnover intention at the Head Office of PT. WG. It also aims to provide input to the management of PT. WG regarding things that need to be done to improve job satisfaction, organizational commitment, and LMX.

This study uses a correlational method with primary data collected using a survey method in the form of a questionnaire. Collected data will be analyzed the suitability of the model with the hypothesis that has been proposed. Based on research that has been done, it was found that job satisfaction, organizational commitment, and LMX have a significant effect on turnover intention. Therefore PT. WG needs to pay attention to factors that influence job satisfaction and organizational commitment. In addition, leaders also need to pay attention to their relationships with subordinates. It is expected to reduce employee turnover intention at the Head Office of PT. WG.
\end{abstract}

Keywords - job satisfaction, organizational commitment, leader-member exchange, turnover intention

\section{INTRODUCTION}

Humans have many needs that must be met in their lives. Human needs are classified into three groups, namely primary needs, secondary needs, and tertiary needs. Humans need to work to be able to meet their needs.

There are two major groups of human work, working as employees or as entrepreneurs. Employees are people who work in a particular organization or company to get a wage. The wages obtained are what will be used to meet their daily needs. Employees must continue to work at the company to keep getting paid.

There are many things that cause an employee to survive to work in a company, for example a pleasant work environment, jobs that match interests \& talents,

${ }^{1}$ Budi Wijaya, Department of Technology Management, Institut Teknologi Sepuluh Nopember, Surabaya, 60264, Indonesia. E-mail: budi.30393@gmail.com

${ }^{2}$ Bustanul Arifin Noer, Department of Business Management, Institut Teknologi Sepuluh Nopember, Surabaya, 60264, Indonesia. E-mail: bus4arifin@gmail.com good relationships with superiors, career advancement opportunities, personal development opportunities, and so forth. If there are one or several factors that cause employees to survive in a company are not met, then there will be a desire for employees to leave the company. The desire to leave this company is called turnover intention.

An employee who begins to want to leave a particular company usually has a declining performance. Employees also began to want to find a new job at another company, marked by the employee starting to open job seeking sites. The relationship between employees and their superiors can also be loose because of the desire to switch companies.

It is very clear that turnover intention has a negative impact on a company. Turnover intention can cause a decrease in employee productivity so that it can affect organizational productivity. Besides turnover intention can also lead to a less conducive work atmosphere in an organization. When employees leave the company, the company needs to incur costs to recruit new employees to replace the employees who leave. Companies also need to incur costs and time to retrain their replacement employees from the start [1].

This research uses PT. WG as a research object. PT. WG is a company engaged in the integrated poultry industry. Some business fields carried out by PT. WG is feedmill, breeding farm, commercial farm, slaughter house, further processing, and partnership. PT. WG has business units \& representatives in almost all regions in Indonesia. Total employees of PT. WG of 5833 employees. The head office of PT. WG is located in Surabaya with 400 employees.

The study took the object of employees at the Head Office of PT. WG This object was chosen because based on employee data leaving PT. WG in 2018 showed that the number of employees leaving the Head Office was the highest in 2018, namely 75 employees. A list of 10 locations with the highest number of outgoing employees in 2018 is shown in Table 1.

The number of employees leaving at the Head Office of PT. WG has increased year by year. The most significant increase occurred in 2018 with a percentage increase of $190 \%$. Trends in employees leaving at the Head Office of PT. WG is shown in Figure 1. 
The 1st International Conference on Global Development - ICODEV

November $19^{\text {th }}, 2019$, Rectorate Building, ITS Campus, Sukolilo, Surabaya, Indonesia

TABLE 1 .

LIST OF 10 LOCATIONS WITH THE HIGHEST NUMBER OF OUTGOING EMPLOYEES IN 2018

\begin{tabular}{lc}
\hline \hline \multicolumn{1}{c}{ Location } & $\begin{array}{c}\text { Outgoing } \\
\text { Employees }\end{array}$ \\
\hline Surabaya - Head Office & 78 \\
Gempol Pasuruan & 64 \\
Sukabumi & 56 \\
Singosari & 41 \\
Batu & 20 \\
Nganjuk & 16 \\
Jember & 15 \\
Beji Pasuruan & 14 \\
Lumajang & 14 \\
Situbondo & 12 \\
\hline
\end{tabular}

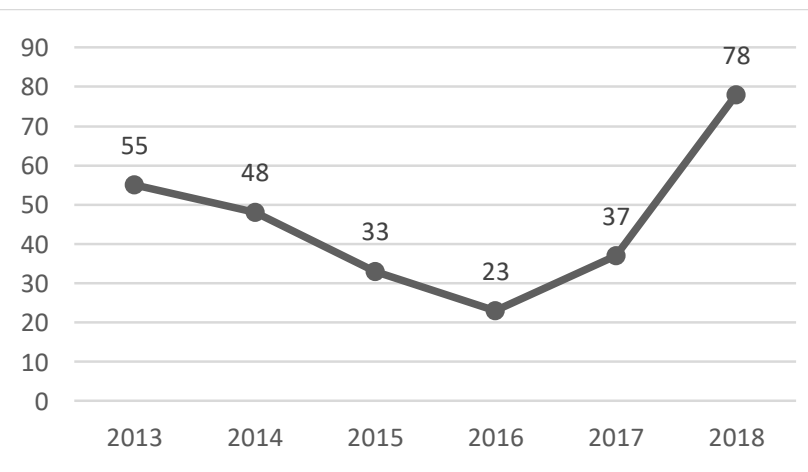

Figure 1. Trends in outgoing employee at the Head Office of PT. WG

The objective of this research is to know the relationship of job satisfaction, organizational commitment, and Leader-Member Exchange (LMX) on turnover intention of Head Office employees in PT. WG. This research also give suggestion to PT. WG management how to increase job satisfaction, organizational commitment, and LMX of Head Office employees in PT. WG.

This research is expected to give examples of empirical finding that show the relationship of job satisfaction, organizational commitment, and LMX on turnover intention. It is also expected as suggestion to management of PT. WG to understand the problem of turnover intention in PT. WG' Head Office, so that will increase the effectivity of company.

\section{METHOD}

By the research objectives, this research classified as correlational research which aims to test whether or not there is a relationship between the variables studied [2]. This research uses survey to get the data, with questionnaire as the research instrument. Research conducted on the population, but the data studied is data from samples taken from the population. The data used in this research is primary data whose data is obtained from the first party or comes from the party who has the data. In this case, data collected from the employees itself.

The research limitation is Head Office employees of PT. WG. Samples taken are 200 respondents. The variables that is used in this research is job satisfaction, organizational commitment, LMX, and turnover intention. The variables classified into two groups. Job satisfaction, organizational commitment, and LMX are classified to exogen variables, while turnover intention is endogen variable.

The data processing and analysis method used is the Structural Equation Model (SEM). The software used is IBM SSPS AMOS 26.0.

The variables to be observed are then described in research indicators. According to Andini [3], Herzberg [4], Meyer \& Allen [5], Schermerhorn [6], and Saeed, et al [7], the indicators that influence each variable are as outlined in Table 2.

TABLE 2.

RESEARCH VARIABLES \& INDICATORS

\begin{tabular}{ll}
\hline \multicolumn{1}{c}{ Variabel } & \\
\hline Exogen: & X1 Satisfaction with company policy \\
Job Satisfaction & X2 Satisfaction of salaries \\
& X3 Satisfaction with the social environment \\
& X4 Satisfaction with work \\
& X5 Satisfaction with recognition from \\
& superiors \\
& X6 Satisfaction with promotion and self \\
& development \\
& X7 Interest in work \\
X8 Responsibility towards work \\
Oxogen: & X9 Involvement in company problems \\
Organizational & X10 Feelings as part of the company \\
Commitment & X11 Responsibility for the success of the \\
& company \\
Xurnover intention & X12 Good communication with superiors \\
Exchange (LMX) & X13 Sufficient attention from superiors \\
& X14 More responsibilities from superiors \\
& X15 Award from the superior \\
Exogen: &
\end{tabular}

The relationship between variables in this study is shown by Figure 2.

Based on the variables, indicators and their relationship, the following hypothesis is proposed:

- H1: Job satisfaction has a negative association with turnover intention

- H2: Organizational commitment has a negative association with turnover intention

- H3: Leader-Member Exchange has a negative association with turnover intention 


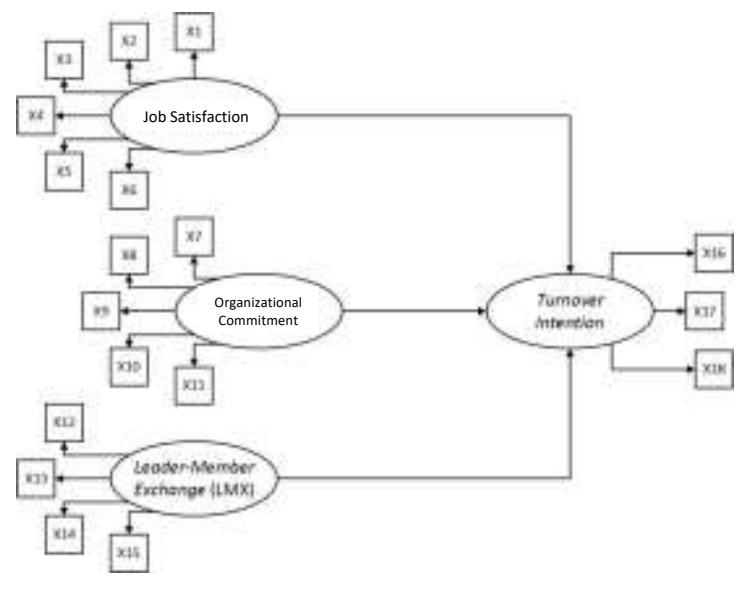

Figure 2. Research model

The sampling technique used in this study is stratified random sampling with proportional sampling approach. The aim is that employees in each division can be represented. The distribution of samples in each division is shown in Table 3.

TABLE 3.

DISTRIBUTION OF SAMPLES IN EACH DIVISION

\begin{tabular}{lcc}
\hline \hline \multicolumn{1}{c}{ Divison } & Employees & Sample size \\
\hline Ayam Pedaging & 72 & $(72 / 400) \times 200=36$ \\
Budidaya & 18 & $(18 / 400) \times 200=9$ \\
TDPA & 9 & $(9 / 400) \times 200=4$ \\
Feed Technology & 5 & $(5 / 400) \times 200=2$ \\
Internal Audit & 17 & $(17 / 400) \times 200=9$ \\
Keuangan \& Akuntansi & 97 & $(97 / 400) \times 200=48$ \\
Logistik & 37 & $(37 / 400) \times 200=19$ \\
Operasional Aquafeed & 5 & $(5 / 400) \times 200=2$ \\
Pemasaran Feed \& DOC & 18 & $(18 / 400) \times 200=9$ \\
Kemitraan & 31 & $(31 / 400) \times 200=16$ \\
Teknologi Informasi & 28 & $(28 / 400) \times 200=14$ \\
Umum & 63 & $(63 / 400) \times 200=32$ \\
TOTAL & $\mathbf{4 0 0}$ & $\mathbf{2 0 0}$ respondents \\
\hline \hline
\end{tabular}

\section{RESUlTS AND DiscUSSION}

The demographic information of the respondents, such as gender, age, education, and work duration are shown in Table 4.

TABLE 4.

DEMOGRAPHIC INFORMATION OF THE RESPONDENTS

\begin{tabular}{llcc}
\hline \hline \multicolumn{1}{c}{ Variables } & \multicolumn{1}{c}{ Category } & Frequency & Percentage \\
\hline Gender & Male & 88 & $44 \%$ \\
Age & Female & 112 & $56 \%$ \\
& 20-25 years old & 110 & $55 \%$ \\
Education & 26-30 years old & 74 & $37 \%$ \\
& 31-35 years old & 16 & $8 \%$ \\
& High School & 4 & $2 \%$ \\
& Diploma & 9 & $4 \%$ \\
Work & Bachelor & 172 & $86 \%$ \\
Duration & Master & 15 & $8 \%$ \\
& - 1 year & 75 & $37 \%$ \\
& 1-3 years & 87 & $43 \%$ \\
& 3-5 years & 13 & $7 \%$ \\
& 5-7 years & 15 & $8 \%$ \\
\hline \hline
\end{tabular}

Hypothesis testing is done based on data that has been collected. The results of testing the hypothesis performed are shown in table 5.

As seen in Table 5, job satisfaction and turnover intention have a negative relationship that is significant ( $\beta=-.514, p=.000)$. These results confirm H1.

Organizational commitment also has a negative relationship that is significant with turnover intention ( $\beta=-.257, p=.041)$. It supports $H 2$.

TABLE 5.

RESULTS OF HYPOTESIS TESTING

\begin{tabular}{|c|c|c|c|c|c|}
\hline Hyp. & $\begin{array}{c}\text { Model } \\
\text { Variables } \\
\end{array}$ & Estimate & 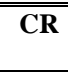 & Prob. & Tesult \\
\hline H1 & $\begin{array}{l}\text { Job Satisfaction } \\
\rightarrow \text { Turnover } \\
\text { Intention }\end{array}$ & -.514 & -4.94 & .000 & Supported \\
\hline H2 & $\begin{array}{l}\text { Organizational } \\
\text { Commitment } \rightarrow \\
\text { Turnover } \\
\text { Intention }\end{array}$ & -.257 & -2.37 & .041 & Supported \\
\hline H3 & $\begin{array}{l}\text { Leader Member } \\
\text { Exchange } \rightarrow \\
\text { Turnover } \\
\text { Intention }\end{array}$ & -.319 & -2.85 & .031 & Supported \\
\hline
\end{tabular}

The third hypothesis is also supported. Based on the result, LMX and turnover intention have a negative relationship that is significant $(\beta=-.319, p=.031)$. It shows that $\mathrm{H} 3$ is supported.

Based on the results, all the hypotheses are supported. In this case, job satisfaction has the most significant effect to turnover intention. It is shown by the number of estimates that is highest $(\beta=-.514)$. It can be concluded that job satisfaction of the employees is the most important factor to make employees stay with the company. Company has to pay attention to the factors that influence job satisfaction such as salary, employee development, and employee promotion. By paying attention to these factors, employees are expected to stay in the company and reduce turnover intention.

Organizational commitment also has important effect to turnover intention. Company needs to make each of employee's role clear. Every employee needs to know that their contribution for the company is important for the company's success. This is expected to engage employees to the company so that employees can stay in the company.

Another factor that is important to reduce turnover intention is the dyadic relationship between leader and the organization member. In this research it is called LMX. Every leader (manager and supervisor) have important role to maintain it. Leaders should retain communication \& relationship with their team member. Giving employees more responsibility is one way to reward employees. With these ways, it is expected that employee will stay with the company. 
The 1st International Conference on Global Development - ICODEV

November $19^{\text {th }}, 2019$, Rectorate Building, ITS Campus, Sukolilo, Surabaya, Indonesia

\section{CONCLUSION}

Based on the results of the analysis conducted, it can be concluded that job satisfaction, organizational commitment, and leader-member exchange have negative effect on turnover intention in Head Office employee of PT. WG. All the three factors have significant effect on turnover intention. Therefore, companies need to pay attention to these three factors so that employees stay in the company and reduce turnover intention. Some ways that can be done by PT. WG to reduce turnover intention are maintain employee salary, employee development, and employee promotion. PT. WG. also needs to make each of employee's role clear to engage employee to the company. Every leader in PT. WG have to retain communication \& relationship with their team member, such as giving employees more responsibility and reward to employees.

\section{REFERENCES}

[1] E. Lambert, "To Stay Or Quit: A Review of the Literature on Correctional Staff Turnover," Am. J. Crim. Justice, vol. VI, 2001.

[2] Sugiyono, Metode Penelitian Manajemen. Bandung: CV Alfabeta, 2013.

[3] R. Andini, "Analisis Pengaruh Kepuasan Gaji, Kepuasan Kerja, Komitmen Organisasional terhadap Turnover Intention (Studi Kasus Pada Rumah Sakit Roemani Muhammadiyah Semarang)," Universitas Diponegoro, Semarang, 2006.

[4] F. Herzberg, Job Satisfaction: Putting Theory into Practice. Leawood: American Academy of Family Physicians, 1993.

[5] J.P. Meyer and N.J. Allen, "A Three-Component Conceptualization of Organizational Commitment," Hum. Resour. Manag. Rev., vol. 1, no. April, 1991.

[6] M. U.-B. J.R. Schermerhorn, J.G. Hunt, R.N. Osborn, Organizational Behavior, 11 th ed. New York, USA.: Wiley, 2011.

[7] M. R. I. Saeed, M. Waseem, S. Sikander, "The Relationship of Turnover Intention with Job Satisfaction, Job Performance, Leader Member Exchange, Emotional Intelligence and Organizational Commitment," Int. J. Learn. Dev., vol. 4, no. August, 2014. 